Int. J. Electrochem. Sci., 11 (2016) $6580-6596$

\title{
Electrochemical Study of Stabilization Higher Oxidation States of d- and f-Metals in Molten Salts
}

\author{
S.A. Kuznetsov \\ Institute of Chemistry, Kola Science Centre of Russian Academy of Sciences, 26a Akademgorodok, \\ Apatity, Murmansk region 184209, Russia \\ *E-mail: kuznet@chemy.kolasc.net.ru
}

doi: $10.20964 / 2016.08 .53$

Received: 11 May 2016 / Accepted: 10 June 2016 / Published: 7 July 2016

Conditions of stabilization higher oxidation states of d- and f-metals in molten salts of various anionic and cationic compositions, which determine, respectively, the composition of the first and second coordination spheres of the complexes, have been studied by voltammetry. The stabilization of higher oxidation states is observed when passing from pure chloride to oxochloride melts and from chloridefluoride to oxofluoride melts. The possibility of stabilization higher oxidation states of chromium in the melts due to the formation of heteronuclear complexes has been demonstrated. It was shown that stabilization of higher oxidation states is accompanied by reaction of disproportionation with formation of fine metal powder in the bulk of the melt and surface coating.

Keywords: molten salts, anionic and cationic compositions, voltammetry, stabilization of higher oxidation states, disproportionation

\section{FULLTEXT}

(C) 2016 The Authors. Published by ESG (www.electrochemsci.org). This article is an open access article distributed under the terms and conditions of the Creative Commons Attribution license (http://creativecommons.org/licenses/by/4.0/). 